\title{
Author Correction: Hybridization is a recurrent evolutionary stimulus in wild yeast speciation
}

\author{
Chris Eberlein 1,2,3,4, Mathieu Hénault 1,3,4,5, Anna Fijarczyk 1,2,3,4, Guillaume Charron (10) 1,2,3,4, Matteo Bouvier 1,2,3, \\ Linda M. Kohn ${ }^{6}$, James B. Anderson (1) ${ }^{6}$ \& Christian R. Landry (1) $1,2,3,4,5$
}

Correction to: Nature Communications https://doi.org/10.1038/s41467-019-08809-7, published online 25 February 2019

Supplementary Information accompanies this paper at https://doi.org/10.1038/s41467-019-09702-z.

The original version of the Supplementary Information associated with this Article contained errors in Supplementary Figures 2, 12, 20 and 22. The HTML has been updated to include a corrected version of the Supplementary Information; the original incorrect versions of these Figures can be found as Supplementary Information associated with this Correction.

(c) Open Access This article is licensed under a Creative Commons Attribution 4.0 International License, which permits use, sharing, adaptation, distribution and reproduction in any medium or format, as long as you give appropriate credit to the original author(s) and the source, provide a link to the Creative Commons license, and indicate if changes were made. The images or other third party material in this article are included in the article's Creative Commons license, unless indicated otherwise in a credit line to the material. If material is not included in the article's Creative Commons license and your intended use is not permitted by statutory regulation or exceeds the permitted use, you will need to obtain permission directly from the copyright holder. To view a copy of this license, visit http://creativecommons.org/licenses/by/4.0/.

(c) The Author(s) 2019

\footnotetext{
${ }^{1}$ PROTEO, The Quebec Network for Research on Protein Function, Engineering, and Applications, Québec, QC G1V 0A6, Canada. ${ }^{2}$ Département de Biologie, Université Laval, Québec, QC G1V OA6, Canada. ${ }^{3}$ Institut de Biologie Intégrative et des Systèmes (IBIS), Université Laval, 1030 Ave de la Médecine, Québec, QC G1V OA6, Canada. ${ }^{4}$ Centre de recherche en données massives (CRDM), Université Laval, Québec, QC G1V OA6, Canada. ${ }^{5}$ Département de Biochimie, Microbiologie et Bio-informatique, Université Laval, Québec, QC G1V OA6, Canada. ${ }^{6}$ Departments of Ecology and Evolutionary Biology and Cell and Systems Biology, University of Toronto Mississauga, 3359 Mississauga Rd, Mississauga, ON L5L 1C6, Canada. These authors contributed equally: Chris Eberlein, Mathieu Hénault. Correspondence and requests for materials should be addressed to C.E. (email: Chris.Eberlein.1@ulaval.ca)

or to C.R.L. (email: Christian.Landry@bio.ulaval.ca)
} 